\title{
Plasma Membrane and Chromaffin Granule Characteristics in Digitonin-Treated Chromaffin Cells
}

\author{
Ronald W. Holz and Ruth A. Senter \\ Department of Pharmacology. The University of Michigan Medical School, Ann Arbor, Michigan, U.S.A.
}

\begin{abstract}
Digitonin permeabilizes the plasma membranes of bovine chromaffin cells to $\mathrm{Ca}^{2+}$, ATP, and proteins and allows micromolar $\mathrm{Ca}^{2+}$ in the medium to stimulate directly catecholamine secretion. In the present study the effects of digitonin $(20 \mu M)$ on the plasma membrane and on intracellular chromaffin granules were further characterized. Cells with surface membrane labeled with $\left[{ }^{3} \mathrm{H}\right]$ galactosyl moieties retained label during incubation with digitonin. The inability of digitonin-treated cells to shrink in hyperosmotic solutions of various compositions indicated that tetrasaccharides and smaller molecules freely entered the cells. ATP stimulated $\left[{ }^{3} \mathrm{H}\right]$ norepinephrine uptake into digitonin-treated chromaffin cells fivefold. The stimulated $\left[{ }^{3} \mathrm{H}\right]$ norepinephrine uptake was inhibited by $1 \mu M$ reserpine, $30 \mathrm{mM} \mathrm{NH}_{4}{ }^{+}$, or $1 \mu M$ carbonyl cyanide $p$-trifluoromethoxyphenylhydrazone (FCCP). The data indicate that $\left[{ }^{3} \mathrm{H}\right]$ norepinephrine was taken up into the intracellular storage granules by the ATP-induced $\mathrm{H}^{+}$electrochemical gradient across the granule membrane. Reduction of the medium osmolality from $310 \mathrm{mOs}$ to $100 \mathrm{mOs}$ was required to release approximately $50 \%$ of the catecholamine from chromaffin granules within digitonin-treated chromaffin cells which indicates a similar osmotic stability to that in intact cells.
\end{abstract}

Chromaffin granules in vitro lost catecholamine when the digitonin concentration was $3 \mu M$ or greater. Catecholamine released into the medium by micromolar $\mathrm{Ca}^{2+}$ from digitonin-treated chromaffin cells that had subsequently been washed free of digitonin could not be pelleted in the centrifuge and was not accompanied by release of membrane-bound dopamine- $\beta$-hydroxylase. The studies demonstrate that $20 \mu M$ of digitonin caused profound changes in the chromaffin cell plasma membrane permeability but had little effect on intracellular chromaffin granule stability and function. It is likely that the intracellular chromaffin granules were not directly exposed to significant concentrations of digitonin. Furthermore, the data indicate that during catecholamine release induced by micromolar $\mathrm{Ca}^{2+}$, the granule membrane was retained by the cells and that catecholamine release did not result from release of intact granules into the extracellular medium. Key Words: Chromaffin cells-Plasma membrane-Chromaffin granules-Digitonin-Norepinephrine. Holz R. W. and Senter R. A. Plasma membrane and chromaffin granule characteristics in digitonintreated chromaffin cells. $J$. Neurochem. 45, 1548-1557 (1985).
The secretion of neurotransmitters and many prepackaged hormones is triggered by a rise in cytosolic $\mathrm{Ca}^{2+}$ which causes fusion of the secretory vesicle membrane with the plasma membrane and release of soluble vesicle contents to the extracellular space by exocytosis. This process was first defined biochemically in investigations concerning catecholamine secretion from adrenal chromaffin cells (for review, see Viveros, 1975), but the underlying events are still unknown. To gain access to the cell interior and to expose the intracellular processes involved in exocytosis to direct experimental ma- nipulation, the plasma membranes of chromaffin cells maintained as monolayer cultures were rendered leaky with the detergent digitonin (Dunn and Holz, 1983; Wilson and Kirshner, 1983) or the closely related substance saponin (Brooks and Treml, 1983), both of which interact with cholesterol.

In the original studies, incubations of 5-15 min with $20 \mu M$ digitonin were sufficient to permeabilize the plasma membrane but caused little leakage of catecholamine from the cells (Dunn and Holz, 1983; Wilson and Kirshner, 1983). The sol-
Received February 27, 1985: accepted May 28, 1985.

Address correspondence to Dr. R. W. Holz at Department of Pharmacology, University of Michigan Medical School, M6322, Medical Science I, Ann Arbor, MI 48109-0010, U.S.A.

Abbreviations used: BSA, bovine serum albumin; EGTA, ethyleneglycol-bis-( $\beta$-aminoethyl ether) $N, N^{\prime}$-tetracetic acid FCCP, carbonyl cyanide $p$-trifluoromethoxyphenylhydrazone; HEPES, $N$-2-hydroxyethyl-piperazine- $N^{\prime}$-2-ethanesulfonic acid; PIPES, piperazine- $N, N^{\prime}$-bis(2-ethanesulfonic acid); PSS, physiological salt solution. 
uble cytosolic marker lactate dehydrogenase rapidly exited from the cells. Digitonin-treated cells secreted catecholamine by exocytosis or by a process very similar to exocytosis in the presence of micromolar $\mathrm{Ca}^{2+}$. In the present study we have further characterized the permeability change induced in the plasma membrane by digitonin. We have also investigated the in situ osmotic stability of chromaffin granules and the ability of chromaffin granules to take up $\left[{ }^{3} \mathrm{H}\right]$ norepinephrine in order to assess chromaffin granule characteristics within digitonin-treated cells.

\section{MATERIALS AND METHODS}

Primary dissociated cells from bovine adrenal medulla were prepared and maintained as monolayer cultures in Eagle's minimal essential medium (GIBCO, Grand Island, NY, U.S.A.) containing $10 \%$ heat-inactivated fetal calf serum as previously described (Fenwick et al., 1978; Holz et al., 1982). The culture medium contained $100 \mathrm{U} /$ $\mathrm{ml}$ of penicillin, $100 \mu \mathrm{g} / \mathrm{ml}$ of streptomycin, $25 \mu \mathrm{g} / \mathrm{ml}$ of gentamycin, and $1.3 \mu \mathrm{g} / \mathrm{ml}$ of Fungizone (Squibb) to prevent bacterial and fungal contamination. The culture medium also contained $10 \mu M$ cytosine arabinoside to inhibit fibroblast growth. Cells were usually cultured as monolayers in 16-mm-diameter plastic culture wells (Costar, Cambridge, MA, U.S.A.) at a density of 250,000 cells/ $\mathrm{cm}^{2}$, in 6.4-mm-diameter plastic culture wells (Costar) at a density of 500,000 cells $/ \mathrm{cm}^{2}$, or in $60-\mathrm{mm}$ plastic petri dishes (Lux, Newbury Park, CA, U.S.A.) at a density of 250,000 cells $/ \mathrm{cm}^{2}$. Experiments were performed $4-14$ days after preparation. There were approximately 40 nmol of catecholamine $/ 10^{6}$ cells. Immediately before an experiment, cells were incubated for $1 \mathrm{~h}$ with physiological salt solution (PSS) containing $145 \mathrm{mM} \mathrm{NaCl}, 5.6 \mathrm{mM}$ $\mathrm{KCl}, 2.2 \mathrm{mM} \mathrm{CaCl}_{2}, 0.5 \mathrm{mM} \mathrm{MgCl}_{2}, 5.6 \mathrm{~m} M$ glucose, 15 $\mathrm{m} M \quad N$-2-hydroxyethyl-piperazine- $N^{\prime}$-2-ethanesulfonic acid (HEPES) (pH 7.4), and $0.5 \mathrm{~m} M$ sodium ascorbate. An experiment was initiated by replacing the medium with new solution. Unless otherwise indicated, experiments were performed at $25^{\circ} \mathrm{C}$.

The potassium glutamate solution that was used for most of the experiments with digitonin contained $139 \mathrm{mM}$ potassium glutamate, $20 \mathrm{~m} M$ piperazine- $N, N^{\prime}$-bis(2-ethanesulfonic acid) (PIPES) (pH 6.6), $1 \mathrm{mM} \mathrm{MgATP}$, and either $5 \mathrm{~m} M$ EGTA (without $\mathrm{Ca}^{2+}$ ) or $5 \mathrm{~m} M$ EGTA and various amounts of $\mathrm{CaCl}_{2}, \mathrm{Ca}^{2+}$ concentrations in $\mathrm{Ca}^{2+}$. EGTA buffers were calculated according to Portzehl et al. (1964). $\mathrm{Mg}^{2+}$ and $\mathrm{Ca}^{2+}$ binding to ATP were calculated based upon the data from Nanninga and Kempen (1971). The $\mathrm{Ca}^{2+}$-EGTA equilibrium was not significantly altered by the concentrations of $\mathrm{Mg}^{2+}$ and ATP that were present. Digitonin $(20 \mu M)$ was used routinely to increase the permeability of the plasma membrane.

Catecholamine release was monitored by determining the percentage of $\left[{ }^{3} \mathrm{H}\right]$ norepinephrine released into the medium from cells that had been previously incubated in $\left[{ }^{3} \mathrm{H}\right]$ norepinephrine-containing solution (Kilpatrick et al., 1980; Dunn and Holz, 1983). The cellular radioactivity was determined after disrupting the cells in $1 \%$ Triton X100 . Dopamine- $\beta$-hydroxylase activity was measured ac- cording to Nagatsu and Udenfriend (1972) in the presence of an optimal $\mathrm{Cu}^{2+}$ concentration $(3 \mu M)$.

$\left[{ }^{3} \mathrm{H}\right]$ Norepinephrine uptake into digitonin-treated chromaffin cells was performed in $\mathrm{Ca}^{2+}$-free potassium glutamate solution containing $1 \mu M\left[{ }^{3} \mathrm{H}\right]$ norepinephrine (2$3 \mu \mathrm{Ci} / \mathrm{ml}$ ) and $0.1 \mathrm{~m} M$ ascorbate. Uptake was terminated by removing the incubation medium and rapidly washing the cells three times with $1 \mathrm{ml}, 0-4^{\circ} \mathrm{C}, \mathrm{Ca}^{2+}$-free potassium glutamate solution without norepinephrine. Cells were disrupted with Triton $X-100(1 \%)$ and the radioactivity determined. In some experiments $\left[{ }^{3} \mathrm{H}\right]$ norepinephrine uptake was determined in solutions containing sucrose or sodium glutamate.

A $\mathrm{P}_{2}$ fraction was prepared by scraping cells off the bottom of a plastic petri dish $(60-\mathrm{mm}$ diameter, 250,000 cells $/ \mathrm{cm}^{2}$ ) in $1.5 \mathrm{ml}$ of $280 \mathrm{~m} M$ sucrose, $10 \mathrm{mM}$ PIPES (pH 6.6), and $1 \mathrm{mM}$ EGTA at $0-4^{\circ} \mathrm{C}$ and homogenizing with 12 vigorous strokes of a $7-\mathrm{ml}$ Dounce homogenizer with a tight-fitting pestle. The homogenate was centrifuged for $10 \mathrm{~min}$ at $800 \mathrm{~g}$. The supernatant was centrifuged for $20 \mathrm{~min}$ at $20,000 \mathrm{~g}$. The pellet ( $\mathrm{P}_{2}$ fraction) was resuspended in $0.25 \mathrm{ml} /$ dish in $0-4^{\circ} \mathrm{C} 280 \mathrm{mM}$ sucrose, $10 \mathrm{~m} M$ PIPES ( $\mathrm{pH} 7.0$ ), and $1 \mathrm{~m} M$ EGTA.

Changes in cell dimensions were recorded by photography with an inverted-phase microscope (Olympus Model IMT with a $35-\mathrm{mm}$ camera) using a $20 \times$ objective. Cells (plated at $125,000 \mathrm{cells} / \mathrm{cm}^{2}$ ) were photographed before and after incubation with various solutions. The images were enlarged 5.3 times. The outlines of cells in control solutions were carefully traced with a fine-tipped, diamond pen on thin, transparent, plastic sheets. Changes in cell shape and size could be accurately assessed by overlaying the transparency onto photographs of the same field after various treatments. This method was able to detect subtle changes in cell shape and changes of less than $5 \%$ in cell dimensions.

The cell surface was labeled with galactosyl moieties by incubating the cells with UDP $\left[{ }^{3} \mathrm{H}\right] g$ alactose and bovine milk UDP-galactose:D-glucose 4- $\beta$-galactosyltransferase according to Torres and Hart (1984). Chromaffin cell monolayers in 6.4-mm-diameter wells were incubated for $30 \mathrm{~min}$ at $25^{\circ} \mathrm{C}$ in $0.025 \mathrm{ml}$ of solution containing 145 $\mathrm{m} M \mathrm{NaCl}, 5.6 \mathrm{~m} M \mathrm{KCl}, 15 \mathrm{~m} M$ HEPES (pH 7.4). $5 \mathrm{~m} M$ $\mathrm{MnCl}_{2}, 10 \mathrm{~m} M$ galactose, $5 \mathrm{mM}$ sodium pyruvate, $2.5 \mathrm{mM}$ AMP, $60 \mu \mathrm{g} / \mathrm{ml}$ aprotinin (Sigma), $6 \mathrm{mg} / \mathrm{ml}$ UDP-galactose:D-glucose 4- $\beta$-galactosyltransferase (EC 2.4.1.22, Sigma), and $40 \mu \mathrm{Ci} / \mathrm{ml}$ uridine disphospho-D-[6${ }^{3} \mathrm{H}$ lgalactose. Cells were rapidly washed three times with $0.3 \mathrm{ml}$ of physiological salt solution. Approximately 6,000 dpm became associated with the cells. Omission of $\beta$ galactosyltransferase from the labeling medium reduced the labeling by $90 \%$. The $\beta$-galactosyltransferase-specific labeling was calculated by subtracting the small amount of radioactivity released into the medium or retained by the cells in culture wells incubated with the labeling solution without $\beta$-galactosyltransferase in parallel experiments.

Sucrose, raffinose, stachyose, and maltodextrin were deionized with Amberlite MB-3 (Mallinckrodt, Paris, KY, U.S.A.). Five grams of carbohydrate and $5 \mathrm{ml}$ of moist resin was agitated continously in $50 \mathrm{ml}$ of deionized water at $4^{\circ} \mathrm{C}$. After $1 \mathrm{~h}$ the resin was removed and washed with $50 \mathrm{ml}$ of deionized water. The wash and the original deionized solution were combined and lyophilized for $\mathbf{4 8}$ 
h. The spectrum of polysaccharides in the maltodextrin fraction was determined using gel chromatography (BioGel P-4, 200-400 mesh, 0.9-cm $\times 280-\mathrm{cm}$ column) with glucose, sucrose, raffinose, and stachyose as standards. The average size, a tetrasaccharide, agreed with the estimate based upon osmolality.

Osmolalities were measured with a vapor pressure osmometer (Wescor, Logan, UT, U.S.A.). Radioactivity was determined by liquid scintillation spectroscopy with a counting efficiency for tritium of $40 \%$.

The low-molecular-weight fraction of maltodextrin was obtained from V-Labs Inc. (Covington, LA, U.S.A.). Bio-Gel P-4, 200-400 mesh was obtained from Bio-Rad Laboratories (Richmond. CA. U.S.A.). $/-\left[7-{ }^{3} \mathrm{H}\right]$ Norepinephrine $(21.4 \mathrm{Ci} / \mathrm{mmol})$ was obtained from Amersham (Arlington Heights, IL, U.S.A.). Data were expressed as mean $\pm S E M$. When the difference between two groups was determined, the SEM was calculated as $\left(\mathrm{SE}^{2}\right.$, + $\left.\mathrm{SE}_{2}^{2}\right)^{1 / 2}$ where $\mathrm{SE}_{1}$ and $\mathrm{SE}_{2}$ are the $\mathrm{SEM}$ for each group. SEM bars smaller than symbols or lines were omitted from figures. Differences between means of groups were tested for significance with Student's $t$ test.

\section{RESULTS}

Permeability changes of the plasma membrane of digitonin-treated chromaffin cells

To characterize the permeability changes induced in chromaffin cells by digitonin, cell shrinkage was examined in potassium glutamate solutions made hyperosmotic with either carbohydrate or salt. The diameter of cells not treated with digitonin shrank by over $30 \%$ within $1 \mathrm{~min}$ after the osmolality was raised from $310 \mathrm{mOs}$ ( $139 \mathrm{~m} M$ potassium glutamate, $20 \mathrm{~m} M$ PIPES, $5 \mathrm{~m} M$ EGTA, pH 6.6) to $900-1000$ mOs with additional potassium glutamate or a variety of polysaccharides (Fig. 1, Table 1). The osmoticants did not equilibrate across the plasma membrane and water left the cells. However, if cells were first incubated for $5 \mathrm{~min}$ in isoosmotic potassium glutamate solution containing digitonin (20 $\mu M)$ and then incubated in hyperosmotic solutions (without digitonin), there was little change in cell shape or size (Fig. 1, Table 1). For example, a lowmolecular-weight fraction of maltodextrin, a corn starch hydrolysate, which contained predominantly 3,4 , and 5 monosaccharide moieties per molecule, caused either no change or less than a $10 \%$ decrease in cell diameter within the first $2 \mathrm{~min}$ (percentages in parentheses in Table 1). The small changes occurred in $62 \%$ of the cells and were largely reversed in $6-10$ min by which time $87 \%$ of the cells had their original size and shape (percentages not in parentheses in Table 1). Solutions made hyperosmotic with stachyose, a tetrasaccharide, gave similar results. Thus, these carbohydrates partially equilibrated across the plasma membrane of digitonintreated cells by 2 min and almost completely equilibrated by $6-10 \mathrm{~min}$. Solutions made hyperosmotic with the disaccharide sucrose or by additional potassium glutamate caused no observable shrinkage even at the earliest times. Sucrose and potassium glutamate, therefore, equilibrated across the plasma membrane within $2 \mathrm{~min}$. These experiments indicate that molecules as large as a tetrasaccharide (approximately 650 daltons) rapidly enter digitonintreated chromaffin cells.

\section{Stability of galactosyl moieties on the surface of chromaffin cells in the presence of digitonin}

Because digitonin disrupts the integrity of the plasma membrane of chromaffin cells, we examined whether surface-labeled membrane is retained by the cells during digitonin treatment. The cell surface was labeled with $\left[{ }^{3} \mathrm{H}\right]$ galactosyl moieties using UDP-galactose:D-glucose-4- $\beta$-galactosyltransferase and UDP $\left[{ }^{3} \mathrm{H}\right]$ galactose. The procedure labels terminal $\mathrm{N}$-acetylglucosamine residues in intact lymphocytes (Torres and Hart, 1984). Intact cells retained over $90 \%$ of the radioactivity in a $30-\mathrm{min}$ incubation. Digitonin treatment of the cells had no effect on the fraction of the radioactivity associated with the cells. It was likely that most of the label was on the outer surface of the cells because omission of $\beta$-galactosyltransferase from the medium inhibited the labeling by $90 \%$. Furthermore, at least $40 \%$ of the surface radioactivity could be removed by incubation of unpermeabilized chromaffin cells with trypsin $(10-40 \mu \mathrm{g} / \mathrm{ml})$. Digitonin did not remove radioactivity from cells labeled at $0-4^{\circ} \mathrm{C}$ to inhibit endocytosis of surface label. The experiments indicate that although digitonin renders the plasma membrane leaky, it does not remove significant amounts of $\left[{ }^{3} \mathrm{H}\right]$ galactose-labeled plasma membrane from the cells.

\section{Sensitivity of chromaffin granules to digitonin}

Digitonin specifically interacts with cholesterol. Because the chromaffin granule membrane contains even more cholesterol than the plasma membrane (Wilson and Kirshner, 1976), it should also be sensitive to digitonin. Indeed, chromaffin granules in vitro that had been isolated from cultured cells labeled with $\left[{ }^{3} \mathrm{H}\right]$ norepinephrine released virtually all the $\left[{ }^{3} \mathrm{H}\right]$ norepinephrine during $20 \mathrm{~min}$ in $10 \mu M$ digitonin (Fig. 2). Half-maximal release occurred between 3 and $10 \mu M$ digitonin. The behavior of chromaffin granules in vitro contrasts with the stability of chromaffin granules within digitonin-treated chromaffin cells. The intracellular granules leak little or no catecholamine during a 15 -min incubation with $20 \mu M$ digitonin (Dunn and Holz, 1983). Higher digitonin concentrations or longer incubations with $20 \mu M$ digitonin causes increased catecholamine leakage from the cells (Dunn and Holz, 1983). It is likely that insufficient digitonin reaches intracellular chromaffin granules to cause release of catecholamine in cells incubated with $20 \mu M$ digitonin for $15 \mathrm{~min}$. Characteristics of chromaffin gran- 
FIG. 1. The effects of hyperosmotic solution containing maltodextrin on the morphology of digitonin-treated and untreated chromaffin cells. Chromaffin cells were incubated with $\mathrm{Ca}^{2+}$-free potassium glutamate solution without MgATP in the absence (A) or presence (B) of $20 \mu \mathrm{M}$ digitonin. After $5 \mathrm{~min}$ the cells were photographed. The solution was then replaced with $\mathrm{Ca}^{2+}$-free potassium glutamate solution supplemented with a low-molecular-weight fraction of maltodextrin (average size equal to a tetrasaccharide) without MgATP or digitonin. Maltodextrin increased the osmolality from 310 to 1,000 mos. The cells were photographed at various times after the solution change as indicated. The phase bright cells are chromaffin cells. Note the marked cell shrinkage in $A$ and virtually no change in cell shape or dimensions in $B$. Cell shrinkage was readily apparent in $A$ within $30 \mathrm{~s}$ of the introduction of the maltodextrincontaining solution.

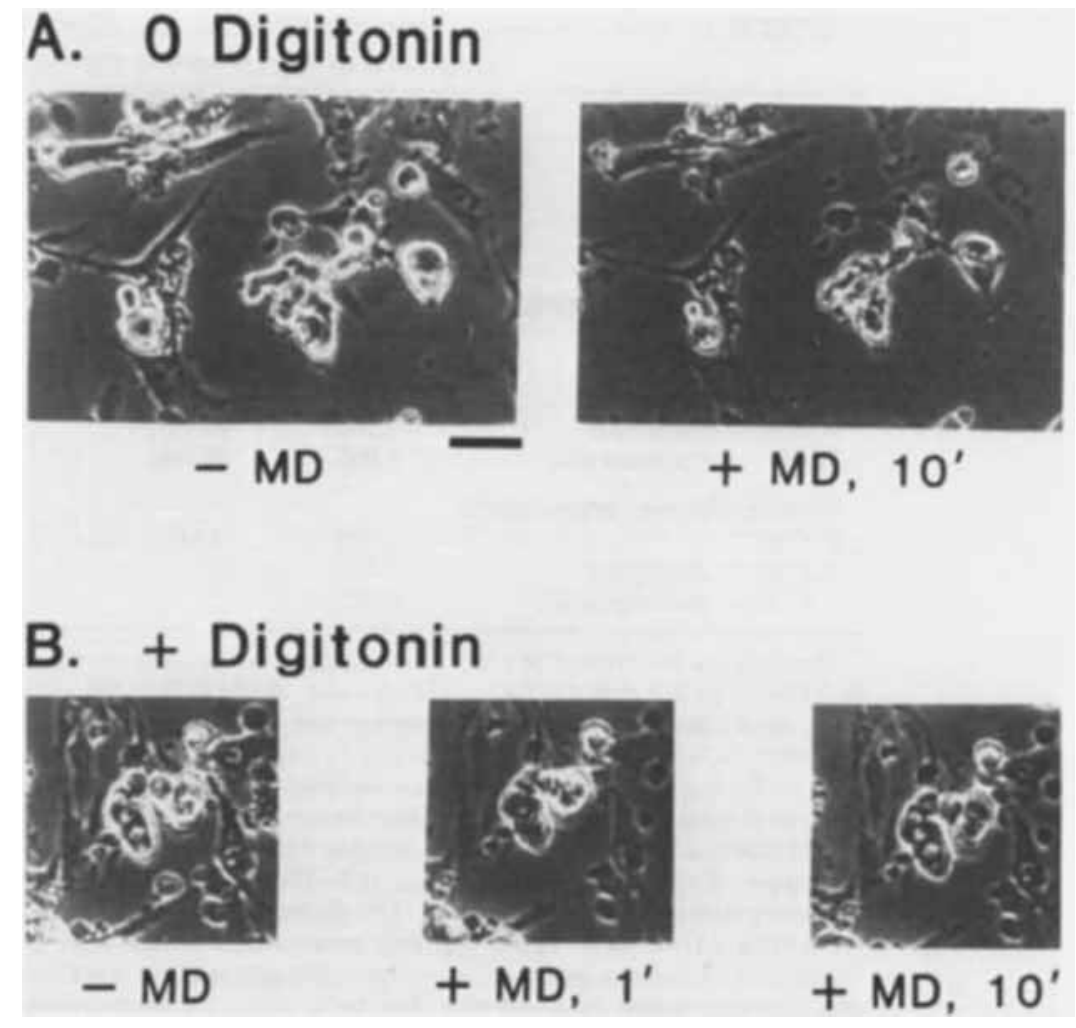

ules within digitonin-treated cells are further assessed below.

\section{MgATP-dependent $\left[{ }^{3} \mathrm{H}\right]$ norepinephrine uptake into chromaffin granules within digitonin-treated chromaffin cells}

A very sensitive indicator of the integrity of chromaffin granule membranes is the ability to maintain a large $\mathrm{H}^{+}$electrochemical gradient across the granule membrane in the presence of $\mathrm{MgATP}$ (Njus et al., 1981). A measure of the $\mathrm{H}^{+}$electrochemical gradient generated by MgATP is catecholamine uptake into granules which is coupled to the gradient (Holz, 1978, 1979; Johnson and Scarpa, 1979; Njus and Radda, 1979; Njus et al., 1981). MgATP stimulated $\left[{ }^{3} \mathrm{H}\right]$ norepinephrine uptake into digitonintreated cells (Fig. 3A). Because the uptake was inhibited by a low concentration of reserpine $(1 \mu M)$, a specific inhibitor of catecholamine uptake into chromaffin granules (Kirshner, 1962) (Table 2), it is likely that $\left[{ }^{3} \mathrm{H}\right]$ norepinephrine was taken up into intracellular chromaffin granules. The three-to fivefold stimulation by ATP of $\left[{ }^{3} \mathrm{H}\right]$ norepinephrine uptake into digitonin-treated chromaffin cells is equal to the in vitro stimulation by ATP of $\left[{ }^{3} \mathrm{H}\right]$ norepinephrine uptake into chromaffin granules prepared from cultured cells that had not been incubated with digitonin (Holz et al., 1983).

The large MgATP-dependent $\left[{ }^{3} \mathrm{H}\right]$ norepinephrine uptake required digitonin treatment of the chromaffin cells and occurred to a similar degree in isoosmotic potassium glutamate, sodium glutamate, and sucrose solutions (Fig. 3B). The relatively small amount of MgATP-stimulated $\left[{ }^{3} \mathrm{H}\right]$ norepinephrine uptake in the absence of digitonin (Fig. 3B) may have occurred in a small fraction of chromaffin cells with damaged plasma membrane or may have oc-

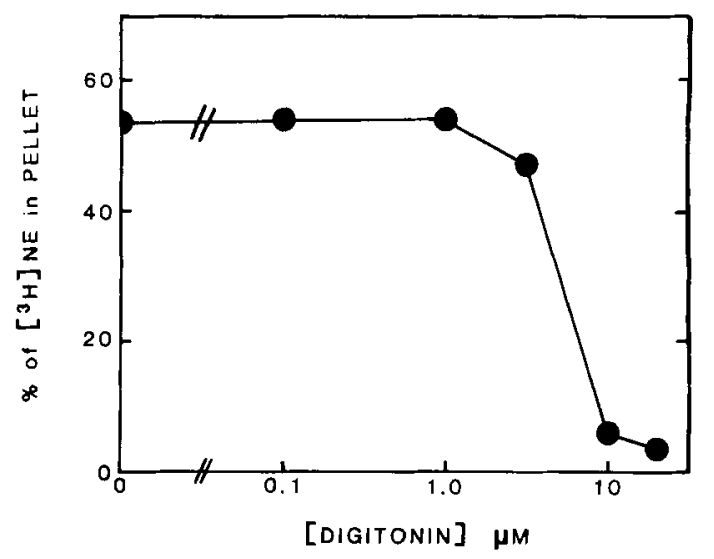

FIG. 2. Ability of various concentrations of digitonin to release $\left[{ }^{3} \mathrm{H}\right]$ norepinephrine from chromaffin granules. $A P_{2}$ fraction was prepared from chromaffin cell cultures that had been labeled with $\left[{ }^{3} \mathrm{H}\right]$ norepinephrine. The suspension was diluted 10 -fold into $139 \mathrm{mM}$ potassium glutamate, $20 \mathrm{mM}$ PIPES, $5 \mathrm{~m} M$ EGTA, $1 \mathrm{~m} M$ MgATP, and various concentrations of digitonin at $25^{\circ} \mathrm{C}$. After $20 \mathrm{~min}$ the granules were pelleted by centrifugation at $20,000 \mathrm{~g} \times 20 \mathrm{~min}$ and the percentage of the total radioactivity in the pellets was determined. There were four samples/group. 
TABLE 1. Size and shape changes of normal and digitonin-treated chromaffin cells subjected to hyperosmotic solutions

\begin{tabular}{lcccc} 
& & \multicolumn{3}{c}{ Percent of total } \\
\cline { 3 - 5 } & mOs & $\begin{array}{c}\text { No size or } \\
\text { shape changes }\end{array}$ & $\begin{array}{c}\text { Shape change } \\
\text { without apparent } \\
\text { size change }\end{array}$ & $\begin{array}{c}\text { Size } \\
\text { decrease }\end{array}$ \\
\hline With digitonin pretreatment & & & & \\
K Glut & 310 & $96(100)$ & $0(0)$ & $4(0)$ \\
K Glut & 950 & $98(94)$ & $0(2)$ & $2(4)$ \\
K Glut + sucrose & 930 & $100(100)$ & $0(0)$ & $0(0)$ \\
K Glut + stachyose & 1,160 & $89(55)$ & $0(11)$ & $11(34)$ \\
K Glut + maltodextrin & 1.000 & $87(38)$ & $0(0)$ & $13(62)$ \\
Without digitonin pretreatment & & & & $96(96)$ \\
K Glut & 950 & $4(4)$ & 0 & 87 \\
K Glut + stachyose & 1,160 & 13 & 0 & 93 \\
K Glut + maltodextrin & 1.000 & 7 & $0(0)$ & \\
\hline
\end{tabular}

Monolayers of chromaffin cells were incubated in isoosmotic potassium glutamate solution (K Glut) in $0 \mathrm{Ca}^{2-}$ (with $5 \mathrm{mM}$ EGTA) in the absence of $\mathrm{MgATP}$ in the presence or absence of digitonin (20 $\mu M)$. At 4.5 min cells were photographed and after $5 \mathrm{~min}$. the solution was replaced with potassium glutamate solution without digitonin, $\mathrm{Ca}^{2-}$, or $\mathrm{MgATP}$ and supplemented with either no additions or with additional potassium glutamate, sucrose, stachyose, or maltodextrin. Size and shape changes were evaluated by photography as described in Material and Methods at $0.5-2.0 \mathrm{~min}$ (percentages in parentheses) and at 6-10 min (percentages without parentheses) after the change in solutions. The diameters of those cells shrunken (at $0.5-2.0 \mathrm{~min}$ or at $6-10 \mathrm{~min}$ ) after digitonin treatment were generally reduced by less than $10 \%$. The diameters of cells shrunken without digitonin pretreatment were reduced $30-40 \%$. Those digitonin-treated cells which were shrunken by $0.5-2.0 \mathrm{~min}$ after introduction of hyperosmotic solutions (percentages in parentheses) invariably enlarged, often to original size and shape by 6-10 min. Similarly, those digitonin-treated cells that were deformed after introduction of hyperosmotic solutions without an obvious size change regained their original shape by 6-10 $\mathrm{min}$. In each group, 25-60 cells were evaluated. The table summarizes results from four different cell preparations.

curred by an entirely different mechanism. The MgATP-dependent uptake in the absence of digitonin was not $\mathrm{Na}^{+}$-dependent and, therefore, was not limited by the $\mathrm{Na}^{+}$-dependent catecholamine transport system of the chromaffin cell plasma membrane (Kenigsberg and Trifaro, 1980).

The effects of $\mathrm{NH}_{4}^{+}$and carbonyl cyanide $p$ trifluoromethoxyphenylhydrazone (FCCP) on $\left[{ }^{3} \mathrm{H}\right]$ norepinephrine uptake into digitonin-treated chromaffin cells were also investigated. $\mathrm{NH}_{4}{ }^{+}(30$ $\mathrm{m} M$ ) increases the $\mathrm{pH}$ within chromaffin granules from 5.3-5.6 to 6.3-6.8 (Johnson and Scarpa, 1979; Holz et al., 1983). FCCP, a $\mathrm{H}^{+}$ionophore, reduces the inside positive, granule membrane potential in the presence of MgATP (approximately $+50 \mathrm{mV}$ ) to the $\mathrm{H}^{+}$equilibrium potential $(-70$ to $-90 \mathrm{mV})$ and, thereby, reduces the $\mathrm{H}^{+}$electrochemical gradient from approximately $120 \mathrm{mV}$ to 0 at $\mathrm{pH} 7$ (Holz, 1978, 1979). Each of these agents, by reducing the $\mathrm{H}^{+}$electrochemical gradient, inhibits ATP-stimulated catecholamine uptake into chromaffin granules in vitro. $\mathrm{NH}_{4}{ }^{+}(30 \mathrm{mM})$ or FCCP $(1 \mu M)$ inhibited by $75 \%$ ATP-stimulated $\left[{ }^{3} \mathrm{H}\right]$ norepinephrine uptake into digitonin-treated chromaffin cells (Table 3 ). The inhibition by these agents further indicates that the ATP stimulated $\left[{ }^{3} \mathrm{H}\right]$ norepinephrine uptake directly into intracellular chro- maffin granules in digitonin-treated cells. Because the uptake was probably coupled to the $\mathrm{H}^{+}$electrochemical gradient across the granule membrane, the results provide further evidence for the functional integrity of the chromaffin granule membrane in digitonin-treated chromaffin cells.

Reserpine (Table 2). $\mathrm{NH}_{4}{ }^{+}$, and FCCP (Table 3) each strongly inhibited intracellular $\left[{ }^{3} \mathrm{H}\right]$ norepinephrine uptake in the absence as well as in the presence of exogenous ATP.

\section{Osmotic stability of chromaffin granules within chromaffin cells}

In a previous study (Hampton and Holz, 1983) we found that intracellular chromaffin granules retain their contents when the intracellular osmolality was decreased from 310 to $200 \mathrm{mOs}$. Significant intracellular chromaffin granule lysis occurred below $150 \mathrm{mOs}$. This behavior contrasts with chromaffin granules in vitro which lose $70-90 \%$ of the contents at $200 \mathrm{mOs}$ (Lishajko, 1970; Hampton and Holz. 1983). To investigate whether the osmotic stability of chromaffin granules within digitonin-treated cells is similar to that within cells not treated with digitonin, chromaffin cells prelabeled with $\left[{ }^{3} \mathrm{H}\right]$ norepinephrine were incubated in isoosmotic potassium glutamate solution containing $20 \mu M$ digitonin, and 

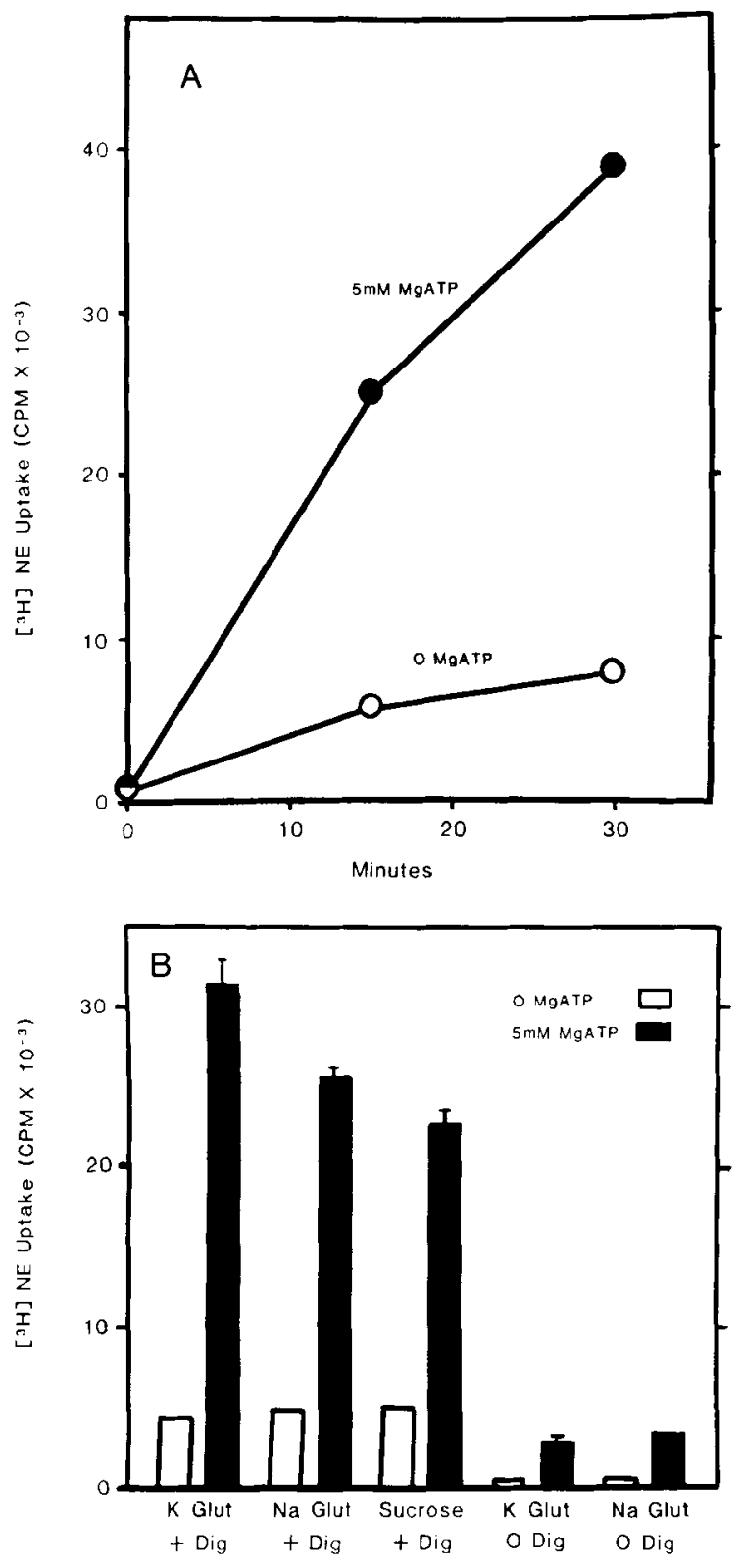

FIG. 3. $\left[{ }^{3} \mathrm{H}\right]$ Norepinephrine uptake into chromaffin cells. A: Time course. Cells were incubated continuously in potassium glutamate solution containing $20 \mu \mathrm{M}$ digitonin, $0.1 \mathrm{mM}$ ascorbate, $1 \mu M\left[{ }^{3} \mathrm{H}\right]$ norepinephrine $(3 \mu \mathrm{Ci} / \mathrm{ml}) \pm 5 \mathrm{mM}$ MgATP. B: Digitonin dependency. Cells were incubated for $30 \mathrm{~min}$ in various solutions containing $\pm 5 \mathrm{mM}$ MgATP, 0.1 $\mathrm{mM}$ ascorbate, $1 \mu \mathrm{M}\left[{ }^{3} \mathrm{H}\right]$ norepinephrine $(2 \mu \mathrm{Ci} / \mathrm{ml} \pm 20 \mu M$ digitonin (Dig). K Glut, potassium glutamate solution; $\mathrm{Na}$ Glut, $139 \mathrm{mM}$ sodium glutamate replaced $139 \mathrm{~m} M$ potassium glutamate; sucrose, $250 \mathrm{mM}$ sucrose replaced $139 \mathrm{mM}$ potassium glutamate. There were four wells/group. $\left[{ }^{3} \mathrm{H}\right]$ Norepinephrine uptake was greater in the presence of MgATP $(p<0.01)$ at 15 and 30 min in $A$ and in all groups in $B$.

then incubated in sucrose solutions of various osmolalities (Fig. 4). The fraction of the total catecholamine released when the osmolality was low-
TABLE 2. Effect of reserpine on $\left[{ }^{3} H\right]$ norepinephrine uptake into digitonin-treated chromaffin cells

\begin{tabular}{clc}
$\begin{array}{c}\text { Group } \\
\text { number }\end{array}$ & No additions & $\begin{array}{c}\text { [3]Norepinephrine } \\
\text { uptake } \\
\left(\mathrm{cpm} \times 10^{3}\right)\end{array}$ \\
\hline 1 & MgATP $(5 \mathrm{~m} M)$ & $2.15 \pm 0.16$ \\
2 & Reserpine $(1 \mu M)$ & $15.7 \pm 1.4$ \\
3 & MgATP $(5 \mathrm{~m} M)+$ reserpine $(1 \mu M)$ & $0.36 \pm 0.06$ \\
4 & $0.45 \pm 0.05$ \\
\hline
\end{tabular}

Chromaffin cells (in 16-mm-diameter wells) were incubated for $30 \mathrm{~min}$ in potassium glutamate solution in the presence of $20 \mu M$ digitonin. $5 \mathrm{mM}$ EGTA, $0.1 \mathrm{~m} M$ ascorbate, $1 \mu M\left[{ }^{3} \mathrm{H}\right]$ norepinephrine $(2 \mu \mathrm{Ci} / \mathrm{ml})$, and the indicated additions. The total catecholamine concentration in the medium was $10 \mu M$ in all groups. A two-factor analysis of variance was completed. There was a significant interaction between reserpine and ATP. Therefore. multiple comparisons were performed with a mean square error from the analysis of variance and an experiment-wise alpha error calculated by the Bonferroni method (Neter and Wasserman, 1974). The following comparisons were significant $(\mathrm{p}<0.01)$ : 2 versus $1 ; 3$ versus $1 ; 4$ versus $1 ; 4$ versus 2 .

ered from 320 to $170 \mathrm{mOs}$ was $20 \%$. Approximately one-half of the $\left[{ }^{3} \mathrm{H}\right]$ norepinephrine in the intracellular granules was released when the osmolality was reduced to $100 \mathrm{mOs}$. Virtually identical effects were observed in ATP-free solution containing $10 \mu \mathrm{M}$ reserpine to inhibit $\left[{ }^{3} \mathrm{H}\right]$ norepinephrine reuptake into the granules. Thus, chromaffin granules within digitonin-treated cells and in intact cells are similarly resistant to osmotic stress.

Over $50 \%$ of the chromaffin granules at $\mathrm{pH} 6.0$ lyse in vitro in the presence of $\mathrm{MgATP}$ and $\mathrm{Cl}^{-}$ (Hoffman et al., 1976). The extent of lysis decreases at higher $\mathrm{pH}$. The $\mathrm{MgATP} / \mathrm{Cl}^{-}$-dependent lysis results from a net uptake of $\mathrm{H}^{+}$and $\mathrm{Cl}^{-}$(Casey et al., 1976). The intragranular $\mathrm{H}^{+}$concentration is buffered, but the increase of intragranular osmolality caused by $\mathrm{Cl}^{-}$induces water influx and osmotic lysis. To examine whether chromaffin granules in digitonin-treated chromaffin cells undergo a similar lysis, digitonin-treated cells were incubated in isoosmotic potassium glutamate or $\mathrm{KCl}$ solutions (pH 6.6) in the presence or absence of $5 \mathrm{mM}$ MgATP for $15 \mathrm{~min}$. Four percent of the total catecholamine was present in the medium in the absence of ATP in both potassium glutamate solution and $\mathrm{KCl}$ solution. Addition of MgATP in potassium glutamate and $\mathrm{KCl}$ solutions caused additional release within $15 \mathrm{~min}$ of less than 2 and $4 \%$, respectively, of the $\left[{ }^{3} \mathrm{H}\right]$ norepinephrine. Thus, chromaffin granules in digitonin-treated cells at $\mathrm{pH} 6.6$ do not undergo extensive lysis in the presence of $\mathrm{Cl}^{-}$and MgATP'. Chromaffin granules within chromaffin cells permeabilized by dielectric breakdown (Knight and Baker, 1982) are also stable in the presence of $\mathrm{Cl}^{-}$and ATP.

1 We also found that chromaffin granules isolated from eultured chromaffin cells released less than $12 \%$ of their catecholamine in $30 \mathrm{~min}$ in $139 \mathrm{mM} \mathrm{KCl}$ and $20 \mathrm{mM}$ PIPES (pH 6.6) in response to $5 \mathrm{~m} M \mathrm{MgATP}$. 
TABLE 3. Effects of FCCP and $\mathrm{NH}_{4}^{+}$on $\left[{ }^{3} \mathrm{H}\right]$ norepinephrine uptake into digitonin-treated chromaffin cells

\begin{tabular}{|c|c|c|c|}
\hline \multirow[b]{2}{*}{ Additions } & \multicolumn{3}{|c|}{$\operatorname{cpm} \times 10^{-3}$} \\
\hline & 0 ATP & $\begin{array}{c}{\left[{ }^{3} \mathrm{H} \mid \text { Norepinephrine }\right.} \\
\text { uptake } \\
5 \mathrm{~m} M \text { ATP }\end{array}$ & $\begin{array}{c}\text { ATP-dependent } \\
{\left[{ }^{3} \mathrm{H}\right] \text { norepinephrine }} \\
\text { uptake }\end{array}$ \\
\hline None & $12.7 \pm 0.6$ & $39.0 \pm 1.4$ & $26.3 \pm 1.5$ \\
\hline $30 \mathrm{mM} \mathrm{NH}_{4}$ & $4.79 \pm 0.22$ & $11.5 \pm 0.4$ & $6.7+0.5^{\prime}$ \\
\hline $1 \mu M$ FCCP & $3.76 \pm 0.15$ & $9.06 \pm 0.2$ & $5.3 \pm 0.5^{a}$ \\
\hline
\end{tabular}

Chromaffin cells (in 16-mm-diameter wells) were incubated for 20 min in potassium glutamate solution in the presence of $20 \mu M$ digitonin. $5 \mathrm{~m} M$ EGTA, $0.1 \mathrm{~m} M$ ascorbate, $1 \mathrm{mM} \mathrm{MgCl}, 1 \mu M\left[{ }^{3} \mathrm{H}\right.$ |norepinephrine $(2 \mu \mathrm{Ci} / \mathrm{ml})$, and the indicated additions. Ammonium was added as the glutamate salt and the potassium glutamate was reduced to maintain isotonicity. The total medium catecholamine concentration was $17 \mu M$ in all groups. There were four wells/group. A two-factor analysis of variance was completed. There was significant interaction between $\mathrm{NH}_{4}{ }^{-}$or FCCP and ATP. Therefore, multiple comparisons using Student 's $t$ test were performed with a mean-square error from the analysis of variance and an experiment-wise alpha error calculated by the Bonferroni method (Neter and Wasserman. 1974). The following comparisons were statistically significant $(\mathrm{p}<0.01)$ : none. $5 \mathrm{mM}$ ATP versus none, $0 \mathrm{ATP} ; \mathrm{NH}_{4}{ }^{+}, 0$ ATP versus none, 0 ATP; FCCP, 0 ATP versus none. 0 ATP: $\mathrm{NH}_{4}{ }^{+} .5 \mathrm{~m} M$ ATP versus none, $5 \mathrm{~m} M$ ATP; FCCP, $5 \mathrm{~m} M$ ATP versus none. $5 \mathrm{mM}$ ATP.

${ }^{a} \mathrm{p}<0.01$ versus ATP-dependent uptake without additions (Bonferroni method).

Because the $\mathrm{Cl}^{-}$- and MgATP-dependent lysis has been suggested to play an important role in exocytosis (Pollard et al., 1979), the effects of isoosmotic $\mathrm{KCl}$ and potassium isethionate on $\mathrm{Ca}^{2+}$-dependent catecholamine secretion were investigated. Isethionate is impermeant across the granule membrane (Dolais-Kitabgi and Perlman, 1975) and does not support MgATP-dependent lysis in vitro (Hoffman et al., 1976). Cells that had been treated for $5 \mathrm{~min}$ with digitonin $(20 \mu M)$ in $139 \mathrm{~m} M$ potassium glutamate. $20 \mathrm{~m} M$ PIPES, $1 \mathrm{~m} M \mathrm{MgATP}$, and $5 \mathrm{~m} M$ EGTA were incubated for $15 \mathrm{~min}$ with or without $10 \mu M \mathrm{Ca}^{2+}$ in the presence of $139 \mathrm{mM}$ potassium glutamate, $139 \mathrm{mM} \mathrm{KCl}$, or $139 \mathrm{~m} M$ potassium isethionate with $20 \mathrm{~m} M$ PIPES and $1 \mathrm{~m} M$ MgATP. $\mathrm{Ca}^{2+}$-dependent secretion in the presence of $\mathrm{KCl}$ or potassium isethionate was 73 or $114 \%$, respectively, of that in the presence of potassium glutamate. Similar results were obtained when isoosmotic sucrose was substituted for potassium glutamate, as had been observed by Wilson and Kirshner (1983). Secretion also occurs in isethionate or sucrose solutions in chromaffin cells permeabilized by dielectric breakdown (Knight and Baker, 1982). Thus, secretion from digitonin-treated chromaffin cells, dielectric breakdown-permeabilized chromaffin cells, or intact cells (Douglas and Rubin, 1963; Kilpatrick et al., 1981) does not require an anion permanent across the chromaffin granule membrane.

Release of particulate and nonparticulate $\left.{ }^{3} \mathrm{H}\right]$ norepinephrine and dopamine- $\beta$-hydroxylase from digitonin-treated chromaffin cells

In previous studies it was demonstrated that the same proportions of soluble dopamine- $\beta$-hydroxylase and catecholamine were released from digitonin-treated cells in response to micromolar $\mathrm{Ca}^{2+}$ (Dunn and Holz, 1983; Wilson and Kirshner, 1983). Although the data were consistent with exocytotic release, it is also possible that granules were released intact from the digitonin-treated cells in a $\mathrm{Ca}^{2+}$-dependent manner. To examine this possibility digitonin-treated chromaffin cells were washed extensively to remove digitonin from the medium and then stimulated to secrete by addition of $10 \mu M \mathrm{Ca}^{2+}$-containing solution. If intact granules were released into the medium, then released catecholamine and chromaffin granule membranes should pellet in the centrifuge. The activity of membrane-bound dopamine- $\beta$-hydroxylase was measured as a granule membrane marker. This protein is a major, integral membrane protein of the chromaffin granule (Hörtnagl et al., 1972) and is not in equilibrium with soluble dopamine- $\beta$-hydroxylase within the granule. $\mathrm{Ca}^{2+}(10 \mu M)$ stimulated secretion of $15 \%$ of the total $\left[{ }^{3} \mathrm{H}\right]$ norepinephrine, of which greater than $90 \%$ could not be sedimented at $50,000 \mathrm{~g} \times 20 \mathrm{~min}$. These conditions are sufficient to pellet chromaffin granules and chromaffin granule membranes (Holz, 1980). The pellet from the centrifugation contained less than $1 \%$ of the total $\left[{ }^{3} \mathrm{H}\right]$ norepinephrine and less than $1 \%$ of the total particulate dopamine- $\beta$-hydroxylase. There was no significant $\mathrm{Ca}^{2+}$-dependent release of either pelletable $\left[{ }^{3} \mathrm{H}\right]$ norepinephrine or particulate dopamine- $\beta$-hydroxylase. These data demonstrate that $\mathrm{Ca}^{2+}$-dependent catecholamine release from digitonin-treated cells does not occur by release of the intact granule into the medium and, in addition, in- 


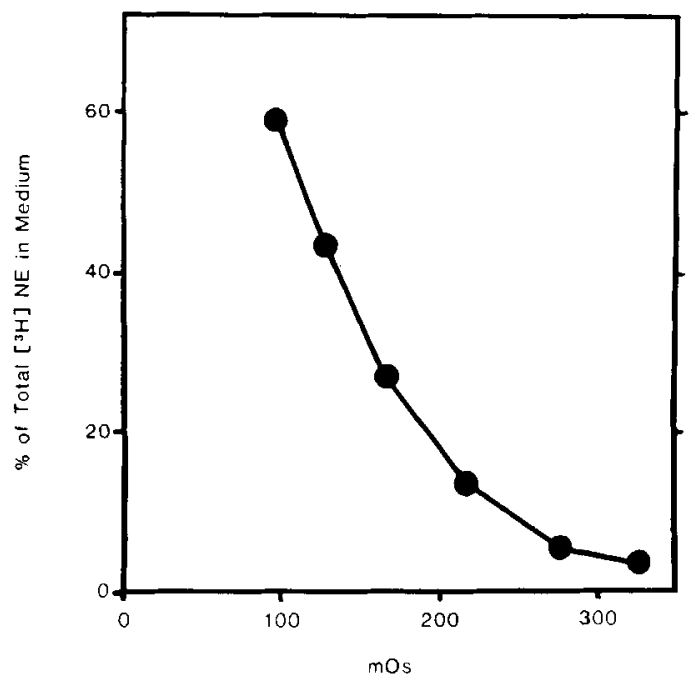

FIG. 4. Effect of decreased osmolality on retention of $\left[{ }^{3} \mathrm{H}\right]$ norepinephrine by chromaffin granules within digitonintreated chromaffin cells. Chromaffin cells were incubated in $\mathrm{Ca}^{2+}$-free potassium glutamate solution with $1 \mathrm{mM} \mathrm{MgATP}$ and $20 \mu M$ digitonin. After 5 min the solution was replaced with $\mathrm{Ca}^{2+}$-free solution without digitonin containing $20 \mathrm{mM}$ PIPES (pH 6.6), $5 \mathrm{mM}$ EGTA, and $1 \mathrm{mM}$ MgATP and various concentrations of sucrose to vary the osmolality. The percentage of radioactivity released into the medium after 15 min was determined. There were four samples/group.

dicate that the granule membrane is retained by the cells.

\section{DISCUSSION}

Plasma membrane and chromaffin granule characteristics in digitonin-treated chromaffin cells

In previous studies, it was demonstrated that 10 $20 \mu M$ digitonin causes large increases in chromaffin cell plasma membrane permeability to $\mathrm{Ca}^{2+}$, ATP, and proteins (Dunn and Holz, 1983; Wilson and Kirshner, 1983). In the absence of $\mathrm{Ca}^{2+}$ there is little or no leakage of catecholamine from the intracellular storage granules (chromaffin granules). Micromolar $\mathrm{Ca}^{2+}$ stimulates release of catecholamine and soluble dopamine- $\beta$-hydroxylase from the intracellular chromaffin granules by exocytosis or a process very similar to exocytosis. The present study further characterizes the effects of digitonin. The inability of digitonin to remove covalently bound, radioactive label from the outer surface of the chromaffin cells indicates that although digitonin greatly increases the plasma membrane permeability, the outer surface of chromaffin cells is not removed. Thin section electron microscopy also suggests the presence of a limiting surface membrane after digitonin treatment (R. W. Holz, unpublished observations).

Approximately $50 \%$ of the lactate dehydrogenase leaves the cells in 10-15 min after addition of 20 $\mu M$ digitonin (Dunn and Holz, 1983) and release continues until $80-100 \%$ is released, even after digitonin is removed from the medium (J. Matejka and R. W. Holz, unpublished observations). Furthermore, a vast majority of the cells stain with trypan blue after $5 \mathrm{~min}$ of digitonin treatment (Dunn and Holz, 1983) and become permeant to sucrose (this study). Thus, a major fraction of the chromaffin cells are rapidly permeabilized by $20 \mu M$ digitonin and could participate in functional responses of the cells.

Profound changes in chromaffin cell plasma membrane permeability induced by short incubations (less than 15 min) with $20 \mu M$ digitonin had little effect on intracellular chromaffin granule function and stability. Not only was there little or no leakage of catecholamine from the cells in the absence of $\mathrm{Ca}^{2+}$, but granules were (a) as resistant to osmotic lysis as granules in intact cells, and (b) able to sustain ATP-induced $\mathrm{H}^{+}$electrochemical gradients that drive granular uptake of catecholamine. Chromaffin granules in vitro rapidly lysed in $20 \mu M$ digitonin. The most likely explanation for the stability and function of chromaffin granules within digitonin-treated chromaffin cells is that they are not directly exposed to significant concentrations of digitonin when the medium contains digitonin at a concentration that is just sufficient to render plasma membranes leaky.

\section{Evidence for exocytotic release of chromaffin granule contents}

Previous studies in digitonin-treated chromaffin cells demonstrated a proportional release of catecholamine and soluble dopamine- $\beta$-hydroxylase induced by micromolar $\mathrm{Ca}^{2+}$ that was consistent with exocytosis (Dunn and Holz, 1983; Wilson and Kirshner, 1983). In the present study, measurement of particulate dopamine- $\beta$-hydroxylase activity, a marker for the chromaffin granule membrane, indicated that the granule membrane was retained by the chromaffin cells after secretion. Thus, the soluble components within chromaffin granules but not the granule membrane were released from digitonin-treated chromaffin cells. The data provide further evidence that secretion from digitonintreated cells occurs by exocytosis.

\section{Endogenous ATP in digitonin-treated cells}

Reserpine, $\mathrm{NH}_{4}{ }^{+}$, and FCCP each strongly inhibited not only $\left[{ }^{3} \mathrm{H}\right]$ norepinephrine uptake into intracellular chromaffin granules in the presence of exogenous ATP as in isolated granules, but also inhibited $\left[{ }^{3} \mathrm{H}\right]$ norepinephrine uptake into intracellular chromaffin granules in the absence of exogenous ATP. Because these agents cause little inhibition of catecholamine uptake into isolated chromaffin granules in the absence of ATP (Holz, 1978; Johnson and Scarpa, 1979), it is likely that in digitonintreated chromaffin cells without added ATP, a sufficient amount of endogenous cytosolic ATP was 
TABLE 4. Release of particulate and nonparticulate $\left[{ }^{3} \mathrm{H} /\right.$ norepinephrine and dopamine- $\beta$-hydroxylase from digitonin-treated chromaffin cells

\begin{tabular}{|c|c|c|c|c|}
\hline [Ca] & $\begin{array}{c}\text { Percent of total } \\
{\left[{ }^{3} \mathrm{H}\right] \text { norepinephrine }} \\
\text { in medium } \\
\text { before } 50,000 \mathrm{~g} \\
\text { centrifugation }\end{array}$ & $\begin{array}{c}\text { Percent of total } \\
{\left[{ }^{3} \mathrm{H}\right] \text { norepinephrine }} \\
\text { in medium } \\
\text { after } 50,000 \mathrm{~g} \\
\text { centrifugation }\end{array}$ & $\begin{array}{c}\text { Percent of total } \\
{\left[{ }^{3} \mathrm{H}\right] \text { norepinephrine in }} \\
50,000 \mathrm{~g} \\
\text { pellet }\end{array}$ & $\begin{array}{c}\text { Percent of total } \\
\text { particulate } \\
\text { dopamine- } \beta \text {-hydroxylase in } \\
50.000 \mathrm{~g} \\
\text { pellet }\end{array}$ \\
\hline $\begin{array}{l}0 \\
10 \mu M\end{array}$ & $\begin{aligned} 3.0 & \pm 0.3 \\
18.3 & \pm 0.4^{a}\end{aligned}$ & $\begin{aligned} 2.5 & \pm 0.3 \\
16.8 & \pm 0.4^{a}\end{aligned}$ & $\begin{array}{l}0.34 \pm 0.05 \\
0.49 \pm 0.04\end{array}$ & $\begin{array}{l}0.53 \pm 0.07 \\
0.56 \pm 0.04\end{array}$ \\
\hline $\begin{array}{l}\mathrm{Ca}^{2+} \text {-dependent } \\
\text { release }\end{array}$ & $15.3 \pm 0.05$ & $14.3 \pm 0.5$ & $0.15 \pm 0.06$ & $0.03 \pm 0.08$ \\
\hline
\end{tabular}

Chromaffin cells prelabeled with [ $\left.{ }^{3} \mathrm{H}\right]$ norepinephrine were incubated with $20 \mu M$ digitonin in $139 \mathrm{~m} M$ potassium glutamate, $20 \mathrm{~m} M$ PIPES, $5 \mathrm{~m} M$ EGTA, $1 \mathrm{mM} \mathrm{MgCl}$, and $1 \mathrm{~m} M \mathrm{MgATP}(\mathrm{pH} 6.60)$. After 5 min the monolayers were washed rapidly with digitonin-free potassium glutamate solution and then incubated for $20 \mathrm{~min}$ in digitonin-free potassium glutamate solution with $5 \mathrm{mg} / \mathrm{ml} \mathrm{BSA} \pm 10$ $\mu M \mathrm{Ca}^{2+}$. The solution was removed and the radioactivity in the cells was determined. The solution was centrifuged at $800 \mathrm{~g} \times 10$ min. The supernatant was carefully removed and $\left[{ }^{3} \mathrm{H}\right]$ norepinephrine in an aliquot was measured. The remainder of the supernatant was recentrifuged at $50,000 \mathrm{~g} \times 20 \mathrm{~min}$. The amount of radioactivity in this supernatant was measured. The high-speed pellet was resuspended in $5 \mathrm{mM}$ PIPES ( $\mathrm{pH} 7.0$ ) and $5 \mathrm{mg} / \mathrm{ml}$ BSA to lyse any sedimented chromaffin granules. The radioactivity released was measured (particulate $\left[{ }^{3} \mathrm{H}\right]$ norepinephrine). The remainder of the supernatant was recentrifuged at $50,000 \mathrm{~g}$ for 20 min and again resuspended in $5 \mathrm{~m} M$ PIPES ( $\mathrm{pH} 7.0$ ) and $5 \mathrm{mg} / \mathrm{ml} \mathrm{BSA}$. The centrifugation and resuspension were repeated two more times. The final resuspension medium contained $5 \mathrm{mM}$ PIPES, $5 \mathrm{mg} / \mathrm{ml} \mathrm{BSA}, 0.05 \%$ Triton X-100, and $64 \mu \mathrm{g} / \mathrm{ml}$ catalase. Dopamine- $\beta$-hydroxylase was measured in the final resuspension (particulate dopamine- $\beta$-hydroxylase). Total particulate dopamine- $\beta$-hydroxylase was measured by scraping and homogenizing monolayers in $5 \mathrm{mM}$ PIPES ( $\mathrm{pH} 7.0$ ) and $5 \mathrm{mg} / \mathrm{ml} \mathrm{BSA}$. The particulate dopamine- $\beta$-hydroxylase was twice sedimented at $50,000 \mathrm{~g} \times 20 \mathrm{~min}$ and resuspended. The final resuspension solution contained $5 \mathrm{~m} M$ PIPES, $5 \mathrm{mg} / \mathrm{ml} \mathrm{BSA}, 0.05 \%$ Triton $\mathrm{X}-100$, and $64 \mu \mathrm{g} / \mathrm{ml}$ catalase. There were four wells/group.

${ }_{a} \mathrm{p}<0.001$ versus $0 \mathrm{Ca}^{2+}$.

present to stimulate $\left[{ }^{3} \mathrm{H}\right]$ norepinephrine uptake. This postulated residual, intracellular ATP may also account for the less than complete dependency of catecholamine secretion on exogenous ATP from digitonin-treated cells (Dunn and Holz, 1983; Wilson and Kirshner, 1983).

\section{Comparison of digitonin treatment and dielectric breakdown}

The first technique that successfully rendered leaky the plasma membrane of chromaffin cells while maintaining exocytosis was dielectric breakdown of the plasma membrane by intense electric fields (Baker and Knight, 1978; Knight and Baker, 1982). The technique, which requires suspended cells, probably causes less drastic permeability changes of the plasma membrane than digitonin treatment. For example, the dielectric breakdown method causes less than $10 \%$ of the lactate dehydrogenase to leave chromaffin cells in $20 \mathrm{~min}$. In contrast, digitonin treatment causes over $50 \%$ of the lactate dehydrogenase to leave cells in a similar time (Dunn and Holz, 1983). Similarly 3-O-methylglucose exits from cells exposed to intense electric fields with a half time of $20 \mathrm{~min}$. The present study demonstrates that sucrose equilibrates across the plasma membrane of digitonin-treated cells within 2 min and carbohydrates as large as the tetrasaccharide stachyose within $6 \mathrm{~min}$. The ability of cells exposed to intense electric fields to maintain soluble cytosolic proteins may account for retention of excellent secretory ability for as long as $50 \mathrm{~min}$ after permeabilization. In contrast, cells treated with dig- itonin lose $50 \%$ of their secretory ability within 10 min (unpublished observations). Neither method of plasma membrane disruption causes disruption of the intracellular chromaffin granules.

The differences in the permeability changes caused by the two techniques have important experimental implications. Exposure to intense electric fields results in leaky cells which give a stable secretory response over many minutes and allows for extended experiments. On the other hand, the extracellular medium equilibrates more rapidly with the intracellular milieu and exogenous proteins such as antibodies and enzymes can probably be introduced more readily in digitonin-treated cells.

Acknowledgment: We thank Dr. Barry Peters (Department of Pharmacology, University of Michigan Medical School) for help in characterizing the polysaccharide content of the maltodextrin fraction. We also thank Dr. Michael A. Schork and Ms. Sandy M. Snedecor (School of Public Health, University of Michigan) for help in the statistical analysis of the data. The work was supported by grants PHS R01 AM27959 and NSF BNS 8211493 to R.W.H. R.W.H. is an Established Investigator of the American Heart Association.

\section{REFERENCES}

Baker P. F. and Knight D. E. (1978) Calcium-dependent exocytosis in bovine adrenal medullary cells with leaky plasma membranes. Nature 276, 620-622.

Brooks J. C. and Treml S. (1983) Catecholamine secretion by chemically skinned cultured chromaffïn cells. J. Newrochem. 40, 468-473.

Casey R. P., Njus D., Radda G. K., and Sehr P. A. (1976) Aden- 
osine triphosphate-evoked catecholamine release in chromaffin granules, osmotic lysis as a consequence of proton translocation. Biochein. J. 158, 583-588.

Dolais-Kitabgi J. and Perlman R. L. (1975) The stimulation of catecholamine release from chromaffin granules by valinomycin. Mol. Pharmacol. 11, 745-750.

Douglas W. W. and Rubin R. P. (1963) The mechanism of catecholamine release from the adrenal medulla and the role of calcium in stimulus-secretion coupling. J. Physiol. (Lond.) $167,288-310$.

Dunn L. A. and Holz R. W. (1983) Catecholamine secretion from digitonin-treated adrenal medullary chromaffin cells. J. Biol. Chem. 258, 4989-4993.

Fenwick E. M., Fajdiga P. B., Howe N. B. S., and Livett B. G. (1978) Functional and morphological characterization of isolated bovine adrenal medullary cells. J. Cell Biol. 76, 1230.

Hampton R. Y. and Holz R. W. (1983) The effects of osmolality on the stability and function of cultured chromaffin cells and the role of osmotic forces in exocytosis. J. Cell Biol. 96, $1082-1088$.

Hoffman P. G., Zinder O., Bonner W. M., and Pollard H. B. (1976) Role of ATP and $\beta$-iminoadenosinetriphosphate in the stimulation of epinephrine and protein release from isolated adrenal secretory vesicles. Arch. Biochem. Biophys. 176, $375-387$.

Holz R. W. (1978) Evidence that catecholamine transport into chromaffin vesicles is coupled to vesicle membrane potential. Proc. Natl. Acad. Sci. USA 75, 5190-5194.

Holz R. W. (1979) Measurement of membrane potential of chromaffin granules by accumulation of triphenylmethylphosphonium cation. J. Biol. Chem. 254, 6703-6709.

Holz R. W. (1980) Osmotic lysis of bovine chromaffin granules in isotonic solutions of weak organic acids. J. Biol. Chem. 255, 7751-7755.

Holz R. W., Senter R. A., and Frye R. A. (1982) Relationship between $\mathrm{Ca}^{2+}$ uptake and catecholamine secretion in primary dissociated cultures of adrenal medulla $J$. Neurochem. $39,635-646$.

Holz R. W., Senter R. A., and Sharp R. R. (1983) Evidence that the $\mathrm{H}^{+}$electrochemical gradient across membranes of chromaffin granules is not involved in exocytosis. J. Biol. Chem. 258, 7506-7513.

Hörtnagl H., Winkler H., and Lochs H. (1972) Membrane proteins of chromaffin granules: dopamine $\beta$-hydroxylase, a major constituent. Biochem. J. 129, 187-195.

Johnson R. G. and Scarpa A. (1979) Protonmotive force and catecholamine transport in isolated chromaffin granules. $J$. Biol. Chem. 254, 3750-3760.

Kenigsberg R. L. and Trifaro J. M. (1980) Presence of a high affinity uptake system for catecholamines in cultured bovine adrenal chromaffin cells. Neuroscience 5, 1547-1556.

Kilpatrick D. L., Ledbetter F. H., Carson K. A., Slepetis R., and Kirshner N. (1980) Stability of bovine adrenal medulla cells in culture. J. Neurochem. 35, 679-692.

Kilpatrick D. L., Slepetis R., and Kirshner N. (1981) Ion channels and membrane potential in stimulus-secretion coupling in adrenal medulla cells. $J$. Neurochem. 36, 1245-1255.

Kirshner, N. (1962) Uptake of catecholamine by a particulate fraction of the adrenal medulla. J. Biol. Chem. 237, 23112317.

Knight D. E. and Baker P. F. (1982) Calcium-dependence of catecholamine release from bovine adrenal medullary cells after exposure to intense electric fields. J. Membr. Biol. 68, $107-140$.

Lishjako F. (1970) Osmotic factors determining the release of catecholamines from isolated chromaffin granules. Acta Physiol. Scand. 79, 64-75.

Nagatsu T. andUdenfriend S. (1972) Photometric assay of dopamine- $\beta$-hydroxylase activity in human blood. Clin. Chem. 18, 980-983.

Nanninga L. B. and Kempen R. (1971) Role of magnesium and calcium in the first and second contraction of glycerin-extracted muscle fibers. Biochemistry 10, 2449-2456.

Neter J. and Wasserman W. (1974) Applied Linear Statistical Models Regression, Analysis of Variance and Experimental Design, p. 480. Richard D. Irwin. Inc., Homewood, IL.

Njus D. and Radda G. K. (1979) A potassium ion diffusion potential causes adrenaline uptake in chromaffin-granule 'ghosts'. Biochem. J. 180, 579-585.

Njus D., Knoth J., and Zallakian M. (1981) Proton-linked transport in chromaffin granules. Curr. Top. Bioenerg. 11, 107147.

Pollard H. B., Pazoles C. J., Creutz C. E.. and Zinder O. (1979) The chromaffin granule and possible mechanisms of exocytosis. Int. Rev. Cytol. 58, 159-197.

Portzehl H., Caldwell P. C., and Ruegg J. C. (1964) The dependence of contraction and relaxation of muscle fibers from the crab Maia Squinado on the internal concentration of free calcium ions. Biochim. Biophys. Acta 79, 581-591.

Torres C. R. and Hart G. W. (1984) Topography and polypeptide distribution of terminal $N$-acetylglucosamine residues on the surfaces of intact lymphocytes. J. Biol. Chem. 259, 33083317.

Viveros O. H. (1975) Mechanism of secretion of catecholamines from adrenal medulla, in Handbook of Physiology Endocrinology (Blaschko H., Sayers G., and Smith A. D., ed), Section 7, Vol. 6, pp. 389-426. American Physiological Society, Washington, D.C.

Wilson S. P. and Kirshner N. (1976) Isolation and characterization of plasma membranes from the adrenal medulla. $J$. Neurochem. 27, 1280-1298.

Wilson S. P. and Kirshner N. (1983) Calcium-evoked secretion from digitonin-permeabilized adrenal medullary chromaffin cells. J. Biol. Chem. 258, 4994-5000. 